\title{
Research of influence of electrical power infrastructure on regional development: conceptual model, diagnostics of a state and vectors of transformation
}

\author{
Anton Dyachkov \\ Ural State University of Economics, \\ Institute of Management and Information Technologies \\ Department of Statistics, Econometrics and Informatics \\ Ekaterinburg, Russia \\ dyachkov2014@gmail.com
}

\author{
Nadezhda Surnina \\ Ural State University of Economics \\ Institute of Management and Information Technologies \\ Department of Statistics, Econometrics and Informatics \\ Ekaterinburg, Russia \\ decane@usue.ru
}

\author{
Elena Shishkina \\ Ural State University of Economics \\ Institute of Management and Information Technologies \\ Department of Statistics, Econometrics and Informatics \\ Ekaterinburg, Russia \\ le_gre@mail.ru
}

\begin{abstract}
The paper presents a study of the influence the electric power infrastructure exerts on the regional development. The authors suggest a model for assessing the impact of electric power infrastructure on the regional development from a standpoint of insuring the connectivity of the regional economic space. For testing the model Sverdlovsk oblast was taken as an example. The results of the calculations for the period of 20122016 enabled the formulation of the relevant strategic tasks, the direction of development of the regional electric power infrastructure - the formation of the common power grid space, the introduction of methods of interstate or interregional energy partnership into management practice, the transfer of technologies and technical solutions, etc.
\end{abstract}

Keywords - region, electric power infrastructure, economic space, regional development, infrastructure connectivity of space

\section{INTRODUCTION}

Infrastructure provision is an important condition for the territory development. The electric power infrastructure availability, accessibility and quality influence the regional development determining the territory investment attractiveness, the opportunities for doing business, etc.

The modern period of the developed countries power industry development is characterised by the change in a technological paradigm. Process of changes of the existing vertically integrated electric energy sector includes transformations of sources and consumers, architecture of network on a digital technological basis, consumer services, etc. Strategically the transformation of the Russian Federation energy system into an active adaptive intellectual grid, complex industry of provision of the national economy built on the basis of network technologies with vertical and horizontal ties between the system elements is supposed. Therefore, communication, binding properties of infrastructure become increasingly important.

\section{MATERIALS AND Methods (Model)}

The electric power infrastructure is considered as a communication spatial system [1], which determines connectivity, homogeneity of space. Many researchers consider connectivity as a qualitative characteristic of the economic space which determines the morphology and the course of the region's long-term development on the basis of the intensity of various connections (communication, transportation, information, cooperation) between subjects.

Although the connectivity is usually considered [see in more detail studies by by O.V. Inshakova, Chepik A.E., D.P. Frolov, A.G. Granberg, A.G. Polyakova, I.S. Simarova, L.B. Seliverstov A.A., Vardomsky, E.G. Animitsa, A.G. Voronina] $[2$, C. $30 ; 3 ; 4 ; 5 ; 6 ; 7$, C. $15 ; 8]$ as a qualitative characteristic, to evaluate its impact on the economic space when drawing up the programmes of regional development, the quantitative assessment is needed in order to reveal the course of interaction of subjects, the causes and the effects. Connectivity is an indicator of the economic space quality, characterizing its integrity, complementarity, possibility of spatial addition, clustering, ability to grow, "density" within a region. Infrastructure connectivity is considered as a way of 
network interrelation of qualitatively developed territory ubiquity and availability of the standardized quality of infrastructure goods and services.

The authors developed a model for assessing the impact of the electricity infrastructure on the regional development on the basis of assessing the indicators of connectivity of the region's economic space. A distinguishing feature of the offered conceptual model, the system of indicators of assessment is that the its basis is formed by the technical, economic and institutional parameters, for the quantitative evaluation of which it is offered to use the indeces characterizing the region's supply with power, electricity, grid density, content analysis of documents. Formulas for the calculation of indeces (coefficients) are worked out in a way enabling their application on the basis of official statistics. Methodology of assessment is worked out with an assumption that a normal (non- emergency) operation of a power supply system is considered.

This approach allows to evaluate the level of regional electric power infrastructure development, its influence on regional development and as a result - to define the relevant strategic tasks, the vectors of the regional development.

To analyze the connectivity various indicators are used, their dynamics is of a divergent character, i.e. a positive dynamics of some indicators is not necessarily the indicator of growth of connectivity of space (for example, gross regional product energy intensity, number of violations in the power enterprises operation, losses of the electric power) therefore for ensuring the reliability of calculations, the rate of increase) of these indicators is estimated additionally.

Indicators of assessment of electrical power infrastructure role from a standpoint of ensuring connectivity of economic space are presented in table 1 .
TABLE I. SYSTEM OF PARAMETERS OF EVALUATION OF THE CONNECTIVITY OF ELECTRIC ENERGY INFRASTRUCTURE IN THE ECONOMIC SPACE OF THE REGION

\begin{tabular}{|c|c|}
\hline Index & Characteristic \\
\hline Investments in fixed capital & RUB, in thousands \\
\hline $\begin{array}{l}\text { Investments in fixed capital by type } \\
\text { of activity of the production and } \\
\text { distribution of electricity, gas and } \\
\text { water }\end{array}$ & 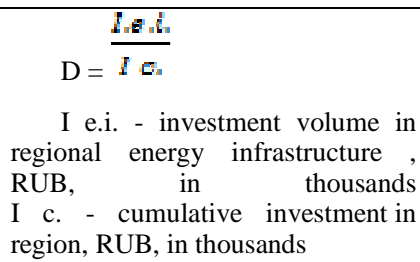 \\
\hline New electrical grid (2014-2016 г.) & Km electrical grid \\
\hline $\begin{array}{l}\text { Gross regional product, mln RUB } \\
(2012-2015)\end{array}$ & RUB, in thousands \\
\hline GRP energy intensity & KgCE / 10 RUB, in thousands \\
\hline The region's supply with power & \begin{tabular}{cc|} 
energy & deficiency \\
overgeneration, & mln. KWh
\end{tabular} \\
\hline Electrical energy consumption & mln kWh \\
\hline Generation of electric power & mln kWh \\
\hline \multirow[t]{2}{*}{$\begin{array}{l}\text { Number of violations in the work of } \\
\text { energy companies }\end{array}$} & $\begin{array}{l}\text { System Average Interruption } \\
\text { Duration Index (SAIDI) } \\
\text { SAIDI = sum of all } \\
\text { customers interruption durations } \\
\text { /total number of customers served }\end{array}$ \\
\hline & $\begin{array}{l}\text { System Average Interruption } \\
\text { Frequency Index (SAIFI) } \\
\text { SAIFI = Total number of customers } \\
\text { interruption/ total number of } \\
\text { customers served }\end{array}$ \\
\hline $\begin{array}{l}\text { Electric or electrical supply to the } \\
\text { electricity grid }\end{array}$ & mln kWh \\
\hline $\begin{array}{l}\text { Electric or electrical supply from } \\
\text { electrical grid }\end{array}$ & mln kWh \\
\hline Energy loss & $\mathrm{mln} \mathrm{kWh}$ \\
\hline \multirow[t]{2}{*}{$\begin{array}{l}\text { Satisfaction of demand for the } \\
\text { electric power }\end{array}$} & $\begin{array}{l}\text { The percent of perform contracts } \\
\text { from the number of effect contracts }\end{array}$ \\
\hline & $\begin{array}{l}\text { The percent of effect contracts from } \\
\text { the number of applications }\end{array}$ \\
\hline \multirow[t]{2}{*}{$\begin{array}{l}\text { Density of the electrical grid in the } \\
\text { region }\end{array}$} & $\begin{array}{l}\text { Density the electricity grid (mln. } \\
\text { RUB / } \mathrm{km} \text { electrical distribution } \\
\text { facility) }\end{array}$ \\
\hline & $\begin{array}{l}\text { Density the electricity grid } \\
(\mathrm{km} / \mathrm{sq} \mathrm{km} \text { land area })\end{array}$ \\
\hline $\begin{array}{l}\text { Number of consumers (in the home } \\
\text { region) }\end{array}$ & Point of delivery, ea \\
\hline $\begin{array}{l}\text { The existence of agreement on } \\
\text { cooperation in energy management }\end{array}$ & Number of agreement, ea \\
\hline
\end{tabular}

Indicators for analysis are to be assessed in dynamics over a five-year period. 
The analysis algorithm assumes that firstly, an average dynamics (average growth rate) of each indicator is determined separately for the period, secondly, calculation of the index of connectivity for all indicators together is defined.

The following formulas are proposed for calculations:

$\mathrm{K}$ - the change in the indicator $\mathrm{x}$ for the period $=\sqrt[4]{(\mathrm{y} 5 /}$

y0 ) (1), where

y5 - the indicator for the reporting period

$\mathrm{y} 0$ is the indicator for the base period

$\mathrm{x} n$ - indicator of connectivity of space

To the connectedness of the space $=$

$\sqrt[n-1]{K \text { of the indicator change }} x 1 *$

$K$ the indicator change $x 2 \ldots * \quad,(2)$ where

\section{$K$ of the indicator change $x n$}

$\mathrm{n}$ is the number of indicators.

As a result of the calculations the space connectivity coefficient space will be received. If $K$ the connectivity of space $>1$, then for the period under review the infrastructure connectivity of space increases. If $K$ the connectivity of space $<1$, for the period under review the infrastructure connectivity of space decreases. If $K$ the connectivity of space $=1$, for the period under review the infrastructure connectivity of space is constant.

\section{RESULTS AND DISCUSSION}

Sverdlovsk oblast was taken as an example for the approbation of calculations (Table 2) was for the period of 5 years $(2012-2016)[9 ; 10 ; 11]$.

On the basis of the values of the indicators of the infrastructural connectivity of the economic space, we define the coefficient of connectedness of the space ( $\mathrm{K}$ of the connectedness of space). To the connectedness of the space $=$

$$
\sqrt[23]{1,005927519}=1,000422233
$$

The analysis of the organization and of the impact of electrical power infrastructure on the regional development shows that in 2012 - 2016 the cumulative coefficient of connectivity increased annually by $0,042 \%$, at the same time the contribution of separate indicators to a total amount varied conditioned upon the general sluggishness of coefficient change. Sverdlovsk oblast was taken as an example for analyzing the main interrelations of a power supply system of the region with the neighboring subjects in 2012-2016. As a result of the evaluation of the infrastructure connectivity of the economic space of the Sverdlovsk oblast, we can conclude that the region is connected to 5 subjects of the Russian Federation by the infrastructure (power grid infrastructure). If the quantity of objects is considered the most intensive interrelations with Perm Krai and Tyumen oblast power supply systems can be observed. The tariff policy is formed individually at the level of each region. Despite interconnections of power systems in the regions under consideration, there are no joint projects for the development of this type of infrastructure, cooperation agreements between regions, etc.

TABLE II. RESULTS OF ESTIMATION OF ELECTRIC ENERGY INFRASTRUCTURE CONNTCTIVENESS IN THE ECONOMIC SPACE OF SVERDLOVSK REGION (2012-2016)

\begin{tabular}{|c|c|}
\hline Index & \begin{tabular}{l}
\multicolumn{2}{c}{ Compound } \\
Annual \\
Rate, $\%$
\end{tabular} \\
\hline Investments in fixed capital & 97,4 \\
\hline $\begin{array}{l}\text { Investments in fixed capital by type of activity } \\
\text { of the production and distribution of electricity, gas } \\
\text { and water }\end{array}$ & 87,7 \\
\hline New electrical grid (2014-2016) & 78,04 \\
\hline Gross regional product, mln RUB (2012-2015) & 106,2 \\
\hline GDP energy intensity (2012-2014) & 89,68 \\
\hline $\begin{array}{l}\text { Excess (-) / deficit (+) power the region's supply } \\
\text { with power (energy deficiency / overgeneration } \\
\text { mln. KWh) }\end{array}$ & 87,93 \\
\hline Electrical energy consumption & 97,83 \\
\hline Generation of electric power & 96,77 \\
\hline $\begin{array}{l}\text { System Average } \quad \text { Interruption } \\
\text { Index (SAIDI) (according to Sverdlovskenergo) }\end{array}$ & $123,48^{*}$ \\
\hline $\begin{array}{l}\text { System Average Interruption Frequency Index } \\
\text { (SAIFI) (according to Sverdlovskenergo) }\end{array}$ & $1,128^{*}$ \\
\hline $\begin{array}{lrlll}\begin{array}{l}\text { Electric or } \\
\text { electrical grid }\end{array} & \text { electrical } & \text { supply } & \text { to the } \\
\end{array}$ & 97,25 \\
\hline $\begin{array}{lllll}\begin{array}{l}\text { Electric or } \\
\text { electrical grid }\end{array} & \text { electrical } & \text { supply } & \text { from } \\
\end{array}$ & 97,25 \\
\hline Energy loss & 97,17 \\
\hline $\begin{array}{l}\text { The percent of perform contracts from the number } \\
\text { of effect contracts }\end{array}$ & 118,6 \\
\hline $\begin{array}{l}\text { The percent of effect contracts from the number of } \\
\text { applications }\end{array}$ & 117,7 \\
\hline $\begin{array}{llcl}\begin{array}{l}\text { Density } \\
\text { (mln. RUB / km electrical distribution facility) }\end{array} & \text { grid } \\
\end{array}$ & $42,98 *$ \\
\hline Density the electricity grid (km/ sq km land area) & $213,09 *$ \\
\hline Number of delivery points, ea & $453578 *$ \\
\hline
\end{tabular}

Thus, despite the connectivity of the regions through the objects of electric network infrastructure is evident the assessment of intensity of interrelations and of the economic viability of maintaining unified tariff policy seems to be difficult. There is no institutional registration of interaction of regions in the sphere of infrastructure facilities development for the current period and strategically. At present the vector of development of the electric power infrastructure of Sverdlovsk region should be aimed at stimulating the development of local electric power infrastructure in the region, the formation of a single electric grid space, the development of a regional, interregional energy infrastructure. 
The improvement of management of regional electrical power infrastructure with due consideration of its impact on the connectivity of economic space is inseparably associated with the analysis and the development of the management model. The specific feature of the management model of power industry development is the necessity to coordinate the interests of participants of infrastructure development management. They differ according to the organization level (federal, regional, local, corporate), and their territorial arrangement (subjects of management are located in different municipal units, territorial subjects of the Russian Federation). The system of the region's electric power infrastructure development management with the consideration of its impact on the connectivity of economic space essentially represents a set of several operating systems (power supply systems of the neighboring regions, regional authorities, consumers etc.) allowing to adopt a metasystem approach to its consideration.

An increase in the level of infrastructure connectivity of the economic space of the region can be put into practice by:

- defining the operational conditions on the basis of agreements, programs and cooperation contracts on infrastructure policy at the level of public authorities, i.e. formal integration;

- interaction of economic entities through the realization of intercompany interaction

The development of approaches to the management of the strategic development of the regional electric power infrastructure should be focused on the efficiency of the implemented solutions. In the authors' view this means the cost effectiveness of the resources (raw materials, financial, temporary, information, material) spent on the improvement of the regional electric power infrastructure, with the consideration of its impact on spatial and social-economic development of the region.

One of the most perspective instruments of managing the strategic development of electrical power infrastructure is the introduction of the principles of partnership (social, marketing, public-private) as the tools for coordinating the economic interests of regional authorities and business entities. Thus, the electric power infrastructure of the territory is considered not only as a set of traditional energy infrastructure objects (pipelines, transmission lines, etc.), but also as a complex of interrelations, including the mechanisms for interstate or interregional energy partnership, transfer of technologies and technical solutions, exchange of energy services.

\section{CONCLUSION}

Taking into account the influence of the electric power infrastructure on regional development the actions aimed at an increase of the efficiency of the regional power industry operation, including technological changes, are considered to be a condition for the growth of the regional social and economic development, for ensuring an effective economic growth of the territory. The results of the analysis can be used in the management practices of the region when the directions of the regional development with the account of the role of electric power infrastructure are worked out. It view of this the justification of the directions of the regional electrical power infrastructure development acquires a special significance.

\section{Acknowledgment}

The article was prepared with the financial support of the Russian Foundation for Basic Research (Project 17-02-00751a) «Mechanisms for the Creation of Effective Infrastructure Energy Supply for Regional Development (by the Example of the Urals Region)».

\section{References}

[1] D'yachkov A.G. To a question of the organization of communication infrastructure spatial systems of the region / A.G. D'yachkov, N.M. Surnina, E.A. Shishkina // Russian journal of entrepreneurship. - 2016. Volume 17. - No. 24. - Page 3515-3530. - doi: 10.18334/rp.17.24.37264

[2] Animitsa, E.G. Economic space of Russia: problems and prospects / E.G. Animitsa, N.M. Surnina // Economy of the region. - 2006. - No. 3. - Page 34-46.

[3] Chepik, A.E. Investigation of the properties of the economic space of the region using statistical methods / A.E. Chepik // Russian journal of entrepreneurship. - 2013. - No. 24 (246). - Page 127-132.

[4] Vardomskii, L.B. Russian economic space: questions of unity in globalization conditions. Scientific report of M.: IE RAS, 2006.

[5] Ufimtseva E.V., Seliverstov A.A., Shadeiko N.R., Podoprigora Yu.V., Volchkova I.V. , Danilova M.N. Coherence as property of social and economic space, Science today: global challenges and mechanisms of development: materials of the international scientific and practical conference, Marker, Vologda, 2016, 78 - 81 .

[6] Granberg A.G. Economy and sociology of space/ A.G. Granberg//Economic revival of Russia. 2010. No. 4. Page 55-57.

[7] Inshakov, O.V. Institutsionalnost of space in the concept of spatial economy / O.V. Inshakov, D.P. Frolov//Spatial economy. - 2007. - No. 1. - Page 5-21.

[8] Mohammadi, N (Mohammadi, Neda); Taylor, JE (Taylor, John E.) Urban infrastructure - mobility energy flux/Energy DEC 1 the 2017th: 140 Part: 1 P.: 716-728 DOI: 10.1016/j.energy.2017.05.189

[9] Business project: [Electronic resource]. - Access mode: http://russian.doingbusiness.org/

[10] Managements of Federal State Statistics Service in Sverdlovsk region and the Kurgan region: [Electronic resource]. - Access mode: http://sverdl.gks.ru/ (date of the address: 11/14/2017)

[11] World Bank: [Electronic resource].- Access mode: http://www.vsemirnyjbank.org/ - Zagl. from the screen (date of the address - 7/3/2017). Pankrukhin A.P. Marketing of territories. the 2nd of., дополн. - SPb.: St. Petersburg, 2006. C. 41-42, 371. 